\title{
MENINGKATKAN KETERAMPILAN MENULIS TEKS EKSPLANASI MELALUI MODEL EXAMPLE NON EXAMPLE
}

\author{
Silvia Aliece Tya', Indrya Mulyaningsih ${ }^{2}$, Tato Nuryanto ${ }^{3}$ \\ Jurusan Tadris Bahasa Indonesia, IAIN Syekh Nurjati Cirebon \\ silviaaliecet@gmail.com
}

Pertama Diterima: 24 Mei 2019

Bukti Akhir Diterima: 6 Juni 2019

\begin{abstract}
Abstrak
Pembelajaran merupakan kegiatan pembelajaran adanya proses kerja sama antara guru dengan siswa untuk memanfaatkan seperti potensi dan sumber yang ada. Potensi yang bersumber dari dalam diri siswa itu sendiri seperti minat, bakat, dan kemampuan dasar yang dimiliki siswa, termasuk gaya belajar serta potensi yang ada di luar diri siswa seperti lingkungan, sarana dan sumber. Dalam menangkap pembelajaran, siswa kurang didorong untuk mengembangkan suatu kemampuan berpikir. Pada pembelajaran bahasa Indonesia di kelas VIII MTs Madinnatunnajah ditemukan beberapa masalah mulai dari penggunaan metode atau model pembelajaran ceramah tidak cocok pada siswa di dalam sekolah tersebut. Tujuan dalam penelitian ini untuk meningkatkan keterampilan menulis teks eksplanasi menggunakan model excample non excample. Penelitian ini menggunakan penelitian tindakan kelas dengan model Kemmis dan Taggart. Sumber data diambil dari hasil menulis teks eksplanasi siswa. Intrumen dalam penelitian ini yaitu lembar observasi dan lembar tes uraian. Teknik analisis data yaitumenganalisis hasil observasi dari hasil pengamatan yang dicatat sebagai informasi dari kegiatan siswa atau aktivitas siswa dalam pembelajaran dan dilakukan dengan adanya lembar sikap positif dan. Selanjutnya wawancara untuk mengetahui yang menjadi kendala atau menemukan masalah yang dihadapi oleh siswa, untuk dilakukan secara berkelanjutan dari hasil wawancara dengan subjek. Dilakukannya tes uraian sebagai bahan evaluasi atau penilaian untuk pemahaman siswa.Hasil penelitian menunjukkan bahwa: bahwa penerapan model example non example dengan menggunakan media gambar dapat memberikan semangat belajar dan mampu memahami pada pembelajaran teks eksplanasi sehingga siswa dapat menuangkan ide gagasannya dengan menulis teks ekplanasi yang diberikan oleh gurunya. Siswa juga dapat memacu semangat belajar dalam mengikuti pembelajaran. Sikap siswa dapat lebih aktif, siswa mampu untuk mengungkapkan ide gagasannya, dan meningkatnya kemampuan menulis teks eksplanasi. Dengan penerapan model example non example menggunakan media gambar dapat meningkatkan kemampuan menulis siswa dari mulai prasiklus, siklus I, dan siklus II dapat mencapai 3,2\%, 70,96\% dan tingkat ketuntasannya mencapai 96,7\%.
\end{abstract}

Kata Kunci: pembelajaran, teks ekplanasi, model example non example.

\begin{abstract}
Learning is a learning activity where there is a process of cooperation between teachers and students to utilize such potential and existing resources. Potential originating from within the students themselves such as interests, talents, and basic abilities possessed by students, including learning styles and potential that exists outside of students such as the environment, facilities and resources. In capturing learning, students are less encouraged to develop a thinking ability. In Indonesian language learning in class VIII MTs Madinnatunnajah found several problems ranging from the use of teaching methods or learning models not suitable for students in the school. The purpose of this study was to improve the ability to write explanatory texts using the excample non excample model. This study uses classroom action research with Kemmis and Taggart models. Source of data taken from the results of writing explanatory text students. The instruments in this study are the observation sheet and the description test sheet. Data analysis techniques
\end{abstract}


that analyze the results of observations from observations that are recorded as information from student activities or student activities in learning and is done in the presence of a positive attitude sheet and. Next the interview to find out the problems or find problems faced by students, to be carried out continuously from the results of interviews with the subject. The description test is conducted as an evaluation or assessment material for students' understanding. The results of the research show that: the application of the example non example model by using picture media can provide enthusiasm for learning and be able to understand the explanatory text learning so that students can pour their ideas by writing the given explanatory text. by his teacher. Students can also encourage the spirit of learning in following learning. The attitude of students can be more active, students are able to express their ideas, and increase the ability to write explanatory texts. By applying the non example example model using picture media, it can improve the students' writing ability from pre-cycle, cycle I, and cycle II can reach $3.2 \%, 70.96 \%$ and the level of completeness reaches $96.7 \%$.

Keywords: learning, explanatory text, model example non example.

\section{PENDAHULUAN}

Pendidikan adalah sebagai pengalaman belajar pada pembelajaran berlangsung di lingkungan dalam sepanjang hidup, Kadir (2012:59). Undang-Undang No. 20 Tahun 2003 mengenai Sistem Pendidikan Nasional menyatakan bahwa pendidikan adalah suatu proses belajar sebagai usaha sadar dan terencana untuk mewujudkan suasana belajar dan agar peserta didik dapat aktif, maupun mengembangkan potensi dirinya agar memiliki kekuatan spiritual keagamaan, akhlak mulia, kecerdasan, kepribadian, dan pengendalian diri sebagai keterampilan yang diperlukan dirinya, masyarakat, bangsa, dan negara, Sanjaya (2014:2).

Pembelajaran merupakan kegiatan pembelajaran adanya proses kerja sama antara guru dengan siswa untuk memanfaatkan seperti potensi dan sumber yang ada. Potensi yang bersumber dari dalam diri siswa itu sendiri seperti minat, bakat, dan kemampuan dasar yang dimiliki siswa, termasuk gaya belajar serta potensi yang ada di luar diri siswa seperti lingkungan, sarana dan sumber belajar sebagai upaya untuk mencapai tujuan belajar tertentu, Sanjaya (2011:26). Dalam menangkap pembelajaran, siswa kurang didorong untuk mengembangkan suatu kemampuan berpikir. Proses belajar di dalam kelas dapat diarahkan pada kemampuan siswa untuk menghafal, dan otak siswa dipaksa untuk mengingat, menimbun berbagai informasi yang diingat oleh siswa untuk menghubungkan dengan kehidupan sehari-hari, Sanjaya (2014:1).

Motivasi belajar siswa kurang didorong pada kemampuan minat belajar siswa yang dapat memengaruhi adanya penggunaan model pembelajaran yang menggunakan salah satu metode saja yaitu metode ceramah. Hal tersebut dapat memengaruhi kurangnya motivasi belajar siswa untuk menerima informasi dari materi yang diberikan. Model Pembelajaran merupakan salah satu untuk memberikan rangsangan atau stimulan kepada siswa untuk memberikan motivasi belajar sebagai salah satu pendekatan yang dapat mengubah pembelajaran menjadi aktif. Pembelajaran aktif dapat mengubah proses belajar menjadi lebih menyenangkan. Model pembelajaran juga sangat berkaitan dengan gaya belajar siswa dan gaya belajar guru, Hanafiah dan Suhana (2012:41).

Berdasarkan hasil observasi pada saat kegiatan PPL (Praktik Pengalaman Lapangan) pada pembelajaran bahasa Indonesia di kelas VIII MTs Madinnatunnajah Kota Cirebon ditemukan beberapa masalah dari mulai faktor eksternal dan internal. Faktor eksternal yaitu fasilitas sekolah 
yang kurang mendukung dari tidak adanya media infocus, kursi dan meja di dalam kelas juga kurang dengan jumlah siswa, begitupun metode yang digunakan yaitu metode ceramah, sedangkan faktor internal dilihat dari sisi siswa dalam kebiasan di kelas seperti siswa tertidur di kelas, tidak memperhatikan pembelajaran berlangsung, dan siswa menjadi bosan dalam mengikuti pembelajaran. Oleh karena itu, siswa menginginkan pembelajaran yang menyenangkan, baik dari cara guru menyampaikan materi maupun juga dari pembelajaran yang berlangsung. Pembelajaran yang menyenangkan harus bisa membuat siswa lebih semangat untuk belajar.

Adanya faktor-faktor yang memengaruhi pembelajaran siswa juga dapat memengaruhi kemampuan siswa pada menulis. Oleh karena itu, siswa kurang dalam kemampuan menulis dilihat dari pembelajaran teks eksposisi pada saat siswa mengerjakan soal yang diberikan oleh guru. Siswa mengerjakan soal dari materi teks eksposisi dengan soal uraian akan tetapi, siswa kesulitan dalam menulis, hanya saja siswa bisa menuliskan beberapa paragraf saja. Maka siswa menginginkan pembelajaran yang menyenangkan yang bisa didapatkan atau dapat menangkap informasi ketika guru mampu menggunakan metode atau model pembelajaran yang sesuai maupun fasilitas yang tersedia dengan materi yang akan diajarkan dapat membantu juga dan dengan adanya media yang sesuai dalam penyampaian materi. Model pembelajaran mampu membuat proses belajar, siswa lebih giat, semangat, memiliki keterampilan yang diperlukan dirinya, mengembangkan kemampuannya dalam hal menulis, siswa dapat memahami dan menerima materi yang disampaikan oleh gurunya, siswa juga dapat menanggapi dengan aktif, dan mampu menggemari atau menggali kembali untuk menulis.

Masalah yang dihadapi oleh siswa di kelas VIII MTs Madinnatunnajah Kota Cirebon yaitu siswa kurang bersemangat dalam mengikuti pembelajaran karna adanya faktor-faktor eksternal dan internal. upaya untuk meningkatkan keterampilan menulis siswa yaitu dengan adanya penggunaan model pembelajaran yang mampu mengembangkan kemampuan menulis siswa, dan memahami pembelajaran yang telah disampaikan oleh guru. Salah satu model pembelajaran yaitu menggunakan model example non example. Model example non example inidapat mengaktifkan siswa agar tidak merasa bosan untuk mengikuti pembelajaran, dengan model pembelajaran example non example siswa mampu menangkap dan memahami pembelajaran sesuai dengan pelajaran Teks Ekplanasi. Penerapan model pembelajaran example non example dapat meningkatkan keterampilan menulis siswa dengan menggunakan media gambar. Hal ini dapat mendorong untuk melakukan penelitian dengan judul "Meningkatkan Keterampilan menulis Teks Eksplanasi Model Example Non Example".

\section{Kajian Teori}

Teks merupakan suatu konteks situasi dalam bahasa yang berfungsi sebagai bahasa yang sedang melaksanakan tugas tertentu. Bahasa yang dituturkan maupun dituliskan sebagai perincian teks pada wujudnya bahasa, atau juga sebagai bentuk-bentuk sarana lain yang digunakan untuk menyatakan apa saja yang dipikirkan. Teks eksplanasi merupakan suatu teks yang menjelaskan proses terjadinya peristiwa-peristiwa tertentu. Teks Eksplanasi memiliki tujuan yaitu memaparkan dan menjelaskan proses muncul terjadinya peristiwa tertentu untuk menambah ilmu pengetahuan (Mahsun, 2018: 1 dan 33). Teks eksplanasi juga menjelaskan terkait perstiwa-peristiwa alam seperti terjadinya hujan lebat, banjir, longsor, tsunami, gempa bumi, dan peristiwa alam lainnya. Adapun 
peristiwa-peristiwa yang terkait dengan budaya, politik, sosial, dan ekonomi. Teks ini menghubungkan peristiwa atau proses yang terjadinya yang muncul seperti fenomena budaya, alam, politik, sosial, dan sebagainya, Kosasih (2017: 127-129).

Teks eksplanasi memiliki bagian-bagian dalam membuat teks ini. Bagian-bagian tersebut termasuk ke dalam struktur teks eksplanasi. Struktur pada teks eskplanasi ada 3 bagian yaitu:

a) identifikasi fenomena merupakan untuk mengidentifikasi sesuatu yang akan disampaikan adanya suatu kejadian ataupun peristiwa-peristiwa yang terkait dengan masalah sosial, budaya, politik, ekonomi, alam dan fenomena-fenomena lainnya.

b) penggambaran rangkaian kejadian merupakan suatu penjelasan sebagai perincian identifikasi fenomena sebagai kejadian yang relevan. Hal tersebut dapat dilihat pada proses kejadian ataupun peristiwanya.

c) ulasan merupakan suatu penilaian atau komentar dari suatu penggambaran rangkaian kejadian dan ditegaskan kembali penjelasan sebelumnya.

Teks eksplanasi memiliki kaidah-kaidah kebahasaan sebagai berikut.

a) Menggunakan konjungsi kausalitas, seperti sebab, karena, oleh sebab itu, oleh karena itu, sehingga.

b) Menggunakan konjungsi kronologis (hubungan waktu), seperti kemudian, lalu, setelah itu, pada akhirnya.

c) Menggunakan kata benda yang merujuk pada suatu jenis fenomena, bukan pada kata ganti penceritanya. Kata ganti yang dimaksud, seperti burung, tumbuhan, gerhana, dan lan-lain.

d) Pada teks eksplanasi sering ditemukannya kata teknis atau peristilahan yang sesuai dengan topik yang dibahasnya, Kosasih (2017:138-145).

Pembelajaran adalah suatu interaksi antara siswa dengan guru di kelas. Pembelajaran yang menyenangkan bisa membangkitkan motivasi belajar siswa, aktif dalam mengikuti pembelajaran, dan membuat pembelajaran lebih menarik.Pembelajaran aktif pada metode pengajaran akan mengkondisikan siswa untuk selalu melakukan pengalaman belajar yang bermakna, serta dapat berpikir pada saat pembelajaran berlangsung Warsono dan Hariyanto (2013:2,12). Melalui pembelajaran aktif peserta didik diharapkan untuk bertanggung jawab pada pemahamanya sendiri dengan proses belajar yang dapat mengembangkan kesadaran dalam diri peserta didik tentang strategi belajar dan proses berfikir efektif. Pembelajaran aktif merupakan strategi yang digunakan untuk mengoptimalkan proses belajar yang senantiasa memposisikan guru sebagai orang yang menciptakan suasana belajar yang kondusif dan sebagai fasilitator dalam proses belajar, sedangkan peserta didik harus aktif, inovatif dan lingkungan dimanfaatkan sebagai sumber belajar yang kreatif, efektif, dan menarik.

Menulis merupakan salah satu aktivitas berbahasa yang bersifat produktif dan ekspresif. Peserta didik pada umumnya menganggap bahwa menulis itu sangat sulit. Hal itu dikeluhkan oleh banyak siswa di pendidikan dasar dan menengah, mahasiswa di perguruan tinggi pun mengeluhkan sulitnya menulis, Khuzaemah dan Herawati (2017:149). Menulis merupakan hal yang sangat penting untuk pendidikan. Oleh karena itu untuk dapat memudahkan para pelajar atau siswa untuk berpikir dan 
mengembangkan pola pikir. Siswa dapat berpikir secara kritis dapat memudahkan, merasakan, menikmati dalam mengembangkan pola pikirnya, dengan memperdalam daya tanggap atau pemahaman, begitupun dapat memecahkan suatu masalah-masalah yang dihadapi oleh siswa, Tarigan (2008:22-23). Menurut Dalman (2014:3) menulis merupakan bahas tulis yang memiliki tujuan tertentu untuk menuangkan suatu gagasan ataupun ide sebagai kreativitas. Menulis adalah salah satu keterampilan berbahasa. Dengan menulis dapat menumbuhkan dorongan pada diri siswa maupun memiliki kuat agar dapat melatih diri untuk menulis secara terusmenerus agar memiliki kemampuan menulis yang lebih baik. Menulis juga mampu untuk menyikapi potensi maupun kreativitas diri. Selain itu juga dapat mengungkapkan ide-ide ataupun gagasan yang akan disampaikannya, dan mengembangkan potensi diri dengan menyerap berbagai informasi, Sukino (2012: 5-6,10). Menulis juga merupakan suatu ungkapan bahasa dalam bentuk simbol gambar maupun suatu aktivitas kompleks, yang mencakup gerakan lengan, tangan, jari, dan mata sebagai penggabungan aktivitas dalam menulis, Agustin (2011: 65-66).

Kemampuan menulis dapat dilihat dengan mengenali kemampuan potensi diri, menguaai berbagai informasi, mengembangkan ide atau gagasan-gagasan mengorganisasikan ide atau gagasan secara sistematis, meninjau maupun menilai ide atau gagasan secara objektif, memecahkan suatu masalah, membiasakan untuk berpikir dan berbahasa secara tertib, dan mendorong untuk belajar secara aktif, Sukino (2012:8-9). Aktivitas siswa dalam menulis merupakan suatu kemampuan keterampilan berbahasa yang paling dikuasai oleh pembelajar bahasa setelah kemampuan mendengarkan, berbicara, dan membaca dan sebagai usaha untuk mengungkapkan pikiran dan perasaan yang ada pada diri siswa. Dalam tes kemampuan menulis, siswa dapat memperlihatkan kemampuannya, maupun diperlukannya tes yang baik, Iskandarwassid dan Sunendar (2013:248249).

Model pembelajaran merupakan pola untuk merancang pembelajaran. Model pembelajaran juga didefinisikan sebagai langkah pembelajaran dan perangkatnya agar mencapai tujuan pembelajaran. Model pembelajaran disebut pembelajaran aktif bila dipratikkan memungkinkan siswa belajar secara aktif. Keaktifan ini ditandai dengan mengembangkan pola pikir, mendengarkan, merasakan, berbicara, mengamati, dan melakukan. Seluruh pancaindra pada siswa akan bekerja secara sinergis sehingga proses belajarnya optimal, Akbar (2016:49-50). Model pembelajaran merupakan pendekatan untuk memicu atau menyiasati perubahan perilaku siswa secara aktif dan memperhatikan pembelajaran.

Model Example Non Example adalah model pembelajaran yang menggunakan media gambar dalam menyampaian materi pembelajaran yang bertujuan mendorong peserta didik untuk belajar berpikir kritis dengan memecahkan masalah yang terkandung dalam contoh-contoh gambar yang disajikan. Hal tersebut bahwa model pembelajaran example non example menggunakan gambar sebagai media pembelajaran dapat membantu proses belajar mengajar yang dapat mendorong peserta didik lebih melatih diri dalam mengembangkan pola pikirnya, Chotimah dan Fathurrohman (2018:238). Strategi yang diterapkan pada metode ini bertujuan untuk mempersiapkan siswa secara cepat dengan menggunakan dua hal yang terdiri atas example memberikan gambaran akan sesuatu yang menjadi contoh materi yang sedang dibahas, dan non-example memberikan gambaran akan sesuatu yang bukan contoh dari suatu materi yang sedang dibahas, Hamdayama (2014:97). Example non example merupakan model pembelajaran dengan menggunakan gambar, diagram, atau tabel 
sesuai materi bahan ajar dan kompetensi, sajian gambar bisa ditempel atau memakai LCD/OHP, guru memberikan petunjuk kepada peserta didik untuk diskusi kelompok tentang sajian gambar tersebut, mengamati sajian, persentasi hasil kelompok, penyimpulan, dan evaluasi, Chotimah dan Fathurrohman (2018:239).

Kerangka konsep model pembelajaran example non-example antara lain sebagai berikut.

a) Menggeneralisasikan gambar-gambar antara exampe dan non example yang menjelaskan gambar-gambar tersebut dan menyajikannya dalam satu waktu yang telah ditentukan oleh guru dan meminta peserta didik untuk memikirkan perbedaan apa yang terdapat pada dua gambar tersebut. Selama peserta didik memikirkan tentang tiap gambar example dan non-example tersebut, dan menanyakan kepada peserta didik mengenai kedua gambar yang berbeda.

b) Menyiapkan example dan non example tambahan, mengenai konsep yang lebih spesifik untuk mendorong peserta didik memahami yang telah dibuatnya sehingga mampu memahami konsep yang baru.

c) Meminta peserta didik untuk berdiskusi dengan kelompoknya untuk menggeneralisasikan gambar example dan non example. Setelah itu meminta tiap kelompok untuk menginformasikan di kelas untuk mendiskusikannya secara klasikal sehingga tiap peserta didik dapat memberikan argumen dan tanggapan.

d) Sebagai bagian penutup yaitu meminta peserta didik untuk mendeskripsikan gambar tersebut yang telah diperoleh dengan menggunakan gambar yang telah didapat dari example dan nonexample, Chotimah dan Fathurrohman (2018:242).

\section{METODE PENELITIAN}

Penelitian ini, berusaha untuk mendeskripsikan bentuk pembelajaran pada materi teks eksplanasi untuk meningkatkan keterampilan menulis melalui model Example Non Example, maka data yang akan dikumpulkan dalam penelitian bersifat deskriptif yaitu mengenai uraian-uraian kegiatan pembelajaran siswa dan penelitian ini menggunakan desain penelitian tindakan kelas (action research). Penelitian ini dilakukan dengan berkolaborasi antara peneliti dan guru untuk melakukan penelitian di kelas dengan mempersiapkan, merancang, melaksanakan, dan merefleksikan tindakan secara berkolaborasi yang bertujuan untuk memperbaiki proses belajar di kelas melalui suatu tindakan pada siklus-siklus, Kunandar (2012:45). Metode penelitian tindakan merupakan suatu penelitian yang dilakukan antara peneliti dan observer (pengamat), Nasir (2017: $66)$.

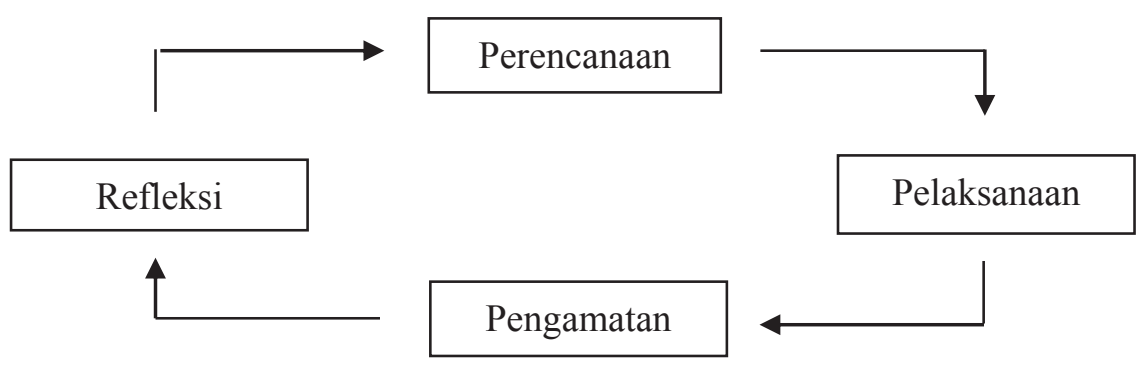

Gambar 2 Alur Penelitian Tindakan Kelas Model Kemmis\& Mc. Taggart, (Arikunto, 2014: 137) 
Penelitian tindakan kelas (action research) memiliki empat tahapan yaitu, perencanaan, tindakan, pengamatan atau pemantauan maupun evaluasi, dan refleksi. Kegiatan pertama dilakukannya observasi terlebih dahulu untuk mengetahui suatu kondisi proses belajar siswa di kelas VIII MTs Madinatunnajah Kota Cirebon, serta melakukan observasi, selanjutnya kegiatan awal yang akan dilakukan di kelas VIII dengan membagikan lembar tes awal yaitu prasiklus atau (pretest) yaitu siswa ditugaskan menulis teks eksplanasi. Setelah selesai mengerjakan tes tersebut, kemudian dikoreksi dan dapat mengetahui kemampuan siswa dalam menulis teks eksplanasi maupun mengetahui masalah-masalah yang dihadapi oleh siswa dalam menulis teks eksplanasi. Langkah selanjutnya yaitu memberikan siklus I.

Teknik yang digunakan pada penelitian ini melalui:

a) Observasi

Teknik pengumpulan data yang digunakan untuk mengamati secara langsung maupun tidak tentang hal-hal yang diamati dan dicatat pada alat observasi. Instrumen observasi yang digunakan untuk mencatat peristiwa-peristiwa yang terjadi untuk diamati masalah (Perdata, 2013: 138). Observasi merupakan pengamatan untuk mendeskripsikan kegiatan-kegiatan siswa dalam mengikuti pembelajaran. Peneliti dapat mengetahui kondisi maupun fakta dalam kegiatan dan tingkah laku siswa di kelas. Penelitian ini bersifat participatif observasion merupakan observasi yang dilaksanakan secara langsung atau adanya keterlibatan secara langsung antara peneliti bersama guru dalam pembelajaran (Sukardi, 2015: 78-79). Observasi adalah aktivitas mencatat suatu gejala atau peristiwa dengan bantuan alat untuk mencatat juna tujuan ilmiah. Prinsip umum dalam melakukan observasi adalah tidak memberikan perlakuan tertentu kepada subjek yang sedang diamati, melainkan dengan membiarkan subjek berucap dan bertindak sama persis dengan kehidupan mereka sehari-hari, Syamsudin (2014:404).

b) Wawancara

Wawancara dapat berbentuk wawancara bebas dan terstruktur. Guru atau peneliti bebas bertanya kepada siswa dan siswa dapat dengan bebas menjawab dalam wawancara bebas. Urutan atau apa yang akan ditanyakan dalam wawancara itu tidak dipersiapkan terlebih dahulu, Hidayah (2018:2077). Wawancara merupakan sebagai teknik dengan bertatap muka secara langsung dengan subjek yang diteliti. Hasil yang didapatkan berupa catatan sebagai informasi penting dalam penelitian, Sukardi (2015:79). Wawancara memiliki tujuan untuk mendapatkan informasi dari subjek yang diteliti dan menggali kembali penelitian secara mendalam, untuk dilakukan secara berkelanjutan, Nusa (2013:225).

c) Tes

Tes merupakan metode yang digunakan dalam penelitian tindakan untuk menjadi tolok ukur dalam pemahaman siswa pada materi dalam proses belajar. Tes ini menggunakan tes uraian untuk mengetahui kemampuan siswa dalam menulis teks eksplanasi, Purnomo (2011:254). Tes tertulis bentuk uraian merupakan seperangkat soal yang berupa tugas, pertanyaan yang menuntut peserta didik untuk mengorganisasikan dan menyatakan jawabannya menurut kata-kata sendiri, Muttaqin dan Kusaeri (2017:3).

Instrumen yang digunakan dalam penelitian ini melalui: 
a) Lembar Observasi

Lembar observasi ini bertujuan untuk mendeskripsikan kegiatan siswa dalam mengikuti pembelajaran di kelas, memperoleh informasi, data, sebagai bahan untuk dicatat untuk menemukan masalah, Sumadayo, (2013:82).

b) Lembar Tes

Bentuk instrumen yang digunakan dalam evaluasi untuk menilai kemampuan berpikir tingkat tinggi adalah tes bentuk uraian. Bentuk tes ini dapat membantu siswa untuk memaksimalkan segala pengetahuan yang dimiliki dalam tulisannya sendiri, dibanding dengan bentuk lain, Sa'adah et al (2013:2).

Tabel 2 Penilaian Teks Eksplanasi

\begin{tabular}{ccc}
\hline No. & Aspek yang dinilai & Skor \\
\hline 1. & Isi & 50 \\
\hline 2. & Struktur & 50 \\
\hline & Jumlah & 100
\end{tabular}

Sumber: Rusmini (2018:43-44)

c) Lembar Sikap

Lembar sikap ini, mendeskripsikan sikap siswa yang sering muncul, dari sikap positif maupun sikap negatif pada perubahan tingkah laku siswa. Menurut Kurniawan (2018: 64-65) dengan menggunakan sisi sikap siswa (afeksi siswa) baik yang positif (on task) maupun negatif (off task) dapat menggambarkan kegiatan siswa dalam mengikuti pembelajaran sebagai berikut.

Tabel 3 Sikap on task dan off task

\begin{tabular}{lll}
\hline \multicolumn{1}{c}{ SikapPositif } & \multicolumn{1}{c}{ SikapNegatif } \\
\hline 1. & Aktif bertanya & 11. Mengerjakan tugas lain \\
\hline 2. & Mengemukakan pendapat & 12. Mengantuk \\
\hline 3. & Mencatat & 13. Mengobrol \\
\hline 4. & Memberikan tanggapan & 14. Mengganggu teman \\
\hline 5. & Memperhatikan & 15. Mondar-mandir \\
\hline 6. & Aktif mengeerjakan tugas yang & 16. Melamun \\
\hline diberikan guru & Merangkum & 17. Absen \\
\hline 8. & Ambisius dalam belajar & 18. Mengeluh \\
\hline 9. & Menyanggah pendapat & 19. Mencoba menarik perhatian \\
\hline 10. Aktif dalam tugas kelompok & 20. Membuat corat-coret \\
\hline
\end{tabular}

Sumber: Kurniawan (2018:64)

Teknik analisis data dilakukan dalam penelitian untuk memperoleh seluruh data dan dapat menarik kesimpulan. Data-data yang dianalisis adalah hasil observasi dari hasil pengamatan yang dicatat sebagai informasi dari kegiatan siswa atau aktivitas siswa dalam pembelajaran dan dilakukan dengan adanya lembar sikap positif dan negatif (off task dan on task) untuk mendeskripsikan atau menggambarkan perilaku siswa dari sisi sikap positif dan negatif dan lembar pengamatan guru. Selanjutnya wawancara untuk mengetahui yang menjadi kendala atau menemukan masalah yang dihadapi oleh siswa, untuk dilakukan secara berkelanjutan dari hasil wawancara dengan subjek. 
Dilakukannya lembar tes (tes uraian) sebagai bahan evaluasi atau penilaian untuk menjadi tolok ukur pemahaman siswa pada materi teks eksplanasi.

Berikut ini rumus untuk mengetahui ketuntasan nilai rata-rata menulis teks eksplanasi siswa yaitu:

$$
\text { Nilai rata-rata }=\quad \frac{\text { Jumlah skor seluruhnya }}{\text { Jumlah seluruh siswa }} \times 100
$$

Berikut ini rumus untuk mengetahui ketuntasan klasikal apabila mencapai $70 \%$ dari total jumlah siswa yang telas mengikuti tes telah mencapai nilai minimal 70.

$$
\text { Ketuntasan Klasikal }=\frac{\text { Jumlah siswa yang mendapat nilai } \geq 70}{\text { Jumlah siswa }} \times 100
$$

\begin{tabular}{|c|c|c|}
\hline Aspek & Kriteria & Skor \\
\hline \multirow{4}{*}{ Isi } & $\begin{array}{l}\text { Sangat mampu: isi sangat sesuai dengan judul, } \\
\text { lengkap, dan jelas. }\end{array}$ & 20 \\
\hline & $\begin{array}{l}\text { Mampu: isi sesuai dengan judul, lengkap, tapi } \\
\text { tidak jelas. }\end{array}$ & 15 \\
\hline & $\begin{array}{l}\text { Kurang mampu: isi sesuai dengan judul, tapi } \\
\text { tidak lengkap dan tidak jelas. }\end{array}$ & 10 \\
\hline & $\begin{array}{l}\text { Tidak mampu: isi tidak sesuai dengan judul, } \\
\text { tidak lengkap, dan tidak jelas. }\end{array}$ & 5 \\
\hline \multirow{4}{*}{ Struktur } & $\begin{array}{l}\text { Sangat mampu: menggunakan ketiga struktur } \\
\text { teks eksplanasi, yaitu identifikasi fenomena; } \\
\text { proses kejadian; dan ulasan. }\end{array}$ & 20 \\
\hline & $\begin{array}{l}\text { Mampu: menggunakan dua struktur teks } \\
\text { eksplanasi. }\end{array}$ & 15 \\
\hline & $\begin{array}{l}\text { Belum mampu: menggunakan satu struktur teks } \\
\text { eksplanasi. }\end{array}$ & 10 \\
\hline & $\begin{array}{l}\text { Tidak mampu: sama sekali tidak menggunakan } \\
\text { struktur teks eksplanasi. }\end{array}$ & 5 \\
\hline
\end{tabular}

Tabel 5 Rubrik Penilaian Teks Eksplanasi

Sumber: Rusmini (2018:43-44)

\section{HASIL PENELITIAN DAN PEMBAHASAN}

\section{Hasil Penelitian}

Pada saat guru memberikan gambaran mengenai teks ekplanasi suasana kelas begitu ramai. Terlihat beberapa siswa yang sedang mengobrol dengan temannya yaitu Fahmi dan Febry, ada juga siswa yang mengantuk pada saat pembelajaran berlangsung yaitu Jajang dengan Rizki, dan siswa yang mengganggu temannya. Melihat kondisi kelas yang tidak kondusif guru segera menenangkan kelas dengan memberikan teguran terhadap siswa yang mengobrol, mengantuk, mondar-mandir dan mengganggu temanya. Melihat kondisi kelas sudah mulai kondusif guru melanjutkan kembali penjelasan materi teks eksplanasi. Setelah pembelajaran berakhir, guru memberikan kesempatan kepada siswa untuk menyimpulkan hasil pembelajaran yang telah didapatkan. Selanjutnya guru menutup pelajaran dengan mengucapkan hamdalah. 
Setelah melakukan observasi terhadap guru, dapat dilihat penggambaran kegiatan belajar mengajar pada siswa kelas VIII di MTs Madinnatunnajah. Kegiatan penelitian selanjutnya diawali dengan melakukan tes yaitu prasiklus atau pretest untuk mengetahui kemampuan siswa dalam menulis teks eksplanasi. Kegiatan ini dilakukan pada hari senin tanggal 11 Februari 2019 dilakukannya prasiklus atau pretest sebelum memasuki siklus I yang di dalamnya terdapat perencanaan, tindakan, pengamatan, dan refleksi. Di hari senin melakukan prasiklus atau pretest, pada prasiklus ini siswa diberikan tes uraian untuk membuat teks eksplanasi. Melihat siswa untuk menulis pada prasiklus ini ditemukan siswa yang tidak menulis. Peneliti melakukan pendekatan dan menanyakan hal yang membuat siswa tersebut tidak menulis. Data hasil tes dari prasiklus atau pretest dapat dilihat pada grafik di bawah ini.

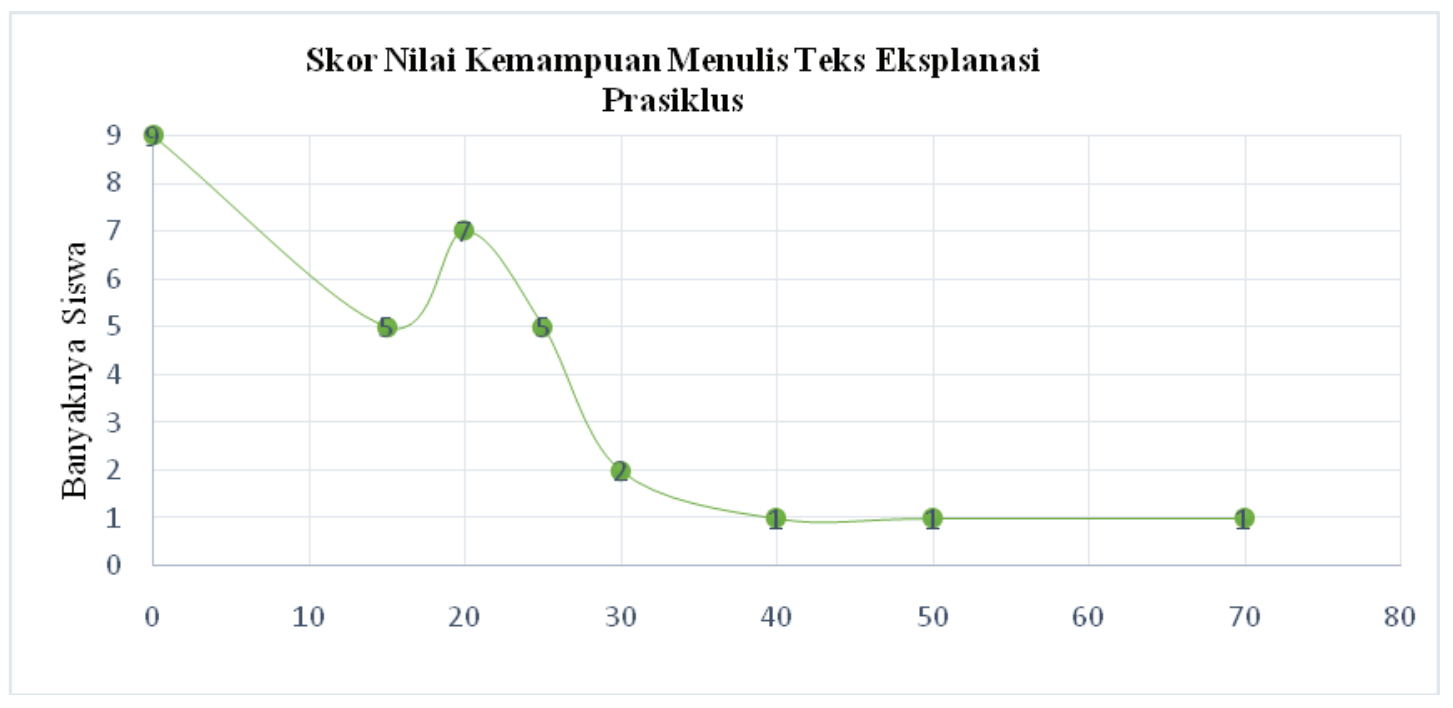

Grafik 1 Hasil Menulis Teks Eksplanasi Prasiklus

Dari data skor nilai di atas, menunjukkan bahwa hasil kemampuan menulis teks eksplanasi siswa yang mendapatkan nilai di bawah KKM 30 orang sedangkan yang mendapatkan skor nilai 70 hanya satu orang yang tuntas yaitu Alya Nur Wulan. Setelah melakukan prasiklus atau pretest menanyakan kepasa siswa yang menjadi kendala dalam menulis teks eksplanasi. Kendala yang dihadapi oleh siswa tersebut, seperti mengeluh untuk mengerjakan tugas, malas untuk menulis, kurang memahami teks eksplanasi, kurang semangat dalam belajar.

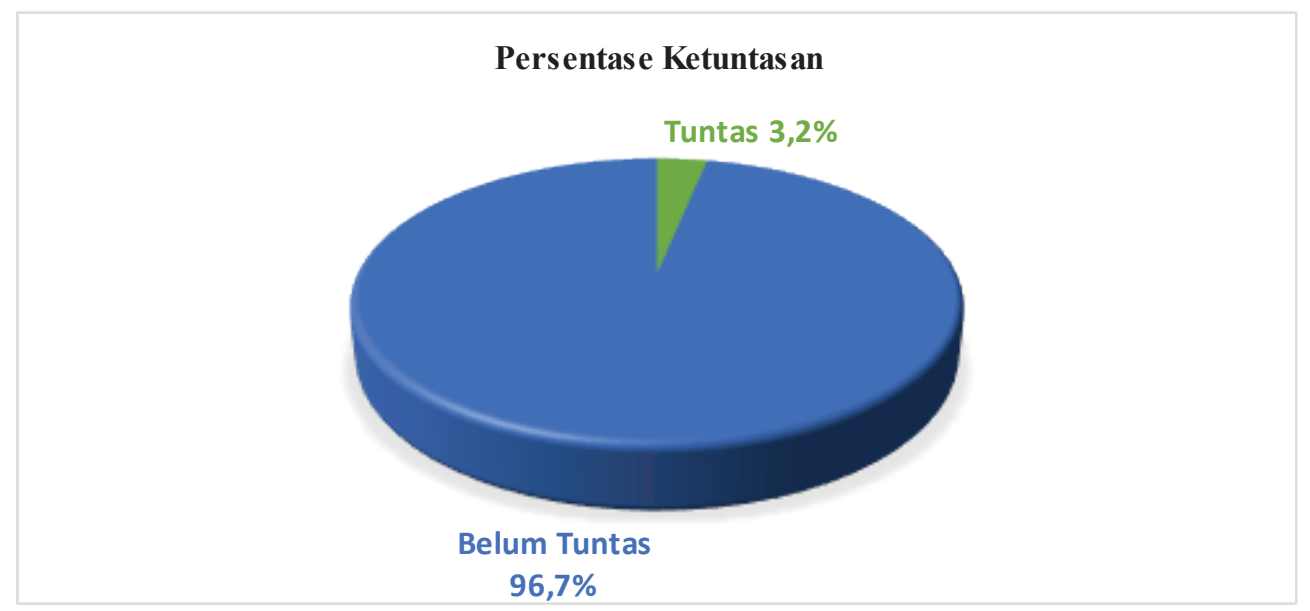

Grafik Lingkaran 2 Persentase Ketuntasan Kemampuan Menulis Teks Eksplanasi Prasiklus (Pretest) 
Berdasarkan dari grafik lingkaran tersebut, siswa yang mendapatkan nilai di bawah 70 adalah 30 siswa yang belum tuntas dengan pesentase $96,7 \%$. Sedangkan siswa yang mendapatkan nilai 70 yang tuntas dengan persentasi 3,2\%. Prasiklus (pretest) ini bahwa persentase ketuntasan siswa dalam menulis teks eksplanasi sangat kurang dari 70\%. Hal tersebut dapat diperbaiki dengan langkah Selanjutnya yang akan dilaksanakan pada siklus I.

Penelitian ini dilaksanakan dua siklus. Pelaksanaan PTK ini dilakukan melalui 2 siklus, siklus pertama ini dilaksanakan pada hari Senin tanggal 18 Februari 2019 dengan alokasi waktu 2 x 40 menit. Siklus kedua, dilaksanakan pada tanggal 21 Februari 2019 dengan alokasi waktu 2 x 40 menit. Kompetensi yang diteliti adalah menulis teks eksplanasi.

\section{Pembahasan}

\section{Pelaksanaan Siklus I}

a. Perencanaan

Peneliti memilih pembelajaran dengan menggunakan model example non example dengan media gambar untuk mengatasi masalah tersebut. Maka disusunlah perencanaan pelaksanaan siklus I (pertama). Adapun rencana yang akan dilaksanakan yaitu: (1) menyusun rencana pelaksanaan pembelajaran (RPP); (2) menyiapkan media pembelajaran; (3) menentukan waktu pelaksanaan tindakan; (4) menyiapkan lembar observasi; dan (5) membuat lembar evaluasi untuk siswa.

b. Pelaksanaan Tindakan Siklus I

Tindakan siklus I dilaksanakan pada pertemuan pertama. Pada pertemuan pertama dilaksanakan pada hari senin 18 Februari 2019. Pertemuan pertama ini dimulai pukul 10.0011.20 WIB. Seluruh siswa hadir sebanyak 31 orang yang terdiri atas laki-laki 16 orang dan perempuan 15 orang. Pelaksanaan pembelajaran dilakukan dengan tiga tahap, yaitu kegiatan pendahuluan, kegiatan inti, dan kegiatan penutup.

1) Kegiatan Pendahuluan

Kegiatan pendahuluan ini diawali dengan guru mengucapkan salam, mengkondisikan kelas, setelah semuanya siap guru membuka kegiatan pembelajaran dengan berdoa dan mengisi daftar hadir siswa. Selanjutnya guru menyampaikan tujuan pembelajaran yaitu: (a) siswa mampu menelaah suatu kejadian mengenai fenomenafenomena dalam teks eksplanasi; (b) siswa dapat menentukkan struktur dan unsur kebahasaan dalam teks eksplanasi; dan (c) siswa mampu membuat teks eksplanasi.

2) Kegiatan Inti

Pembelajaran inti dimulai dengan guru menjelaskan terlebih dahulu materi mengenai pembelajaran menulis teks eksplanasi, selanjutnya mempersiapkan gambar dan menempelkan gambar tersebut di papan tulis. Guru memberikan petunjuk dan memberi kesempatan kepada siswa untuk memperhatikan dan menganalisis gambar tersebut dan diberikan waktu 5 menit. Setelah siswa menganalisis gambar tersebut. 
Guru menanyakan gambar kepada siswa mengenai dua gambar tersebut. Seluruh siswa menjawab gambar pertama yaitu pelangi dan gambar kedua tangan yang memegang handphone. Guru menanyakan kembali kepada siswa terkait gambar yang membahas mengenai teks eksplanasi. Salah satu siswa yang bernama Adam Maulana mengangkat tangannya dan menjelaskan gambar yang pertama, gambar yang pertama termasuk ke dalam teks eksplanasi karena menjelaskan suatu fenomena alam yaitu terjadinya fenomena pelangi.

Guru dan siswa memberikan apresiasi. Selanjutnya guru menanyakan kembali mengenai gambar yang kedua. Seluruh siswa mengungkapkan bahwa gambar tersebut menggambarkan tangan yang sedang memainkan handphone, siswa bingung, terdiam, mengobrol dengan temannya, tidak memperhatikan dan beberapa siswa tidak ada yang menjawab. Guru memberikan teguran kepada siswa yang mengobrol dengan temannya, dan yang tidak memperhatikan. Setelah itu, guru menjelaskan mengenai gambar kedua tangan yang memegang handphone. Bahwa gambar tersebut menjelaskan pengaruh handphone pada lingkungan sosial.

Suasana jadi tidak terkondisikan ( tidak kondusif), ada beberapa siswa yang mengobrol, mondar-mandir, menganggu temannya, dan mengantuk. Melihat kelas yang tidak kondusif guru segera menenangkan siswa di kelas dengan memberikan teguran terhadap siswa yang ribut. lalu siswa terdiam, tenang dan memperhatikan kembali. Melihat kondisi di kelas sudah mulai kondusif guru melanjutkan kembali penjelasan materi teks eksplanasi dengan menerapkan model example non example dengan menggunakan media gambar. Guru membagi 3 kelompok diskusi dan kertas yang berisi wacana untuk menentukan strukturnya maupun isinya, dan mencari perbedaan pada gambar-gambar tersebut dan menjelaskan bagian-bagian struktur dalam teks eksplanasi maupun unsur kebahasaannya.

Guru memberikan petunjuk kepada siswa untuk mencatat hasil diskusi. Tiap-tiap kelompok diberi kesempatan membacakan hasil diskusinya dengan perwakilan tiap-tiap kelompoknya. Selanjutnya kelompok yang lain memberikan tanggapan mengenai paparan dari kelompok yang mempersentasikan hasilnya, dan siswa memberikan apresiasi terhadap perwakilan kelompok yang membacakan hasilnya. Setelah itu selesai diskusi kelompok, guru menyimpulkan hasil pembelajaran yang telah berlangsung, dan guru memberikan evaluasi kepada siswa untuk membuat teks eksplanasi. Ada salah satu siswa yang tidak ingin menulis yaitu bernama Syafiq.

Guru memberikan pendekatan kepada siswa tersebut. Siswa tersebut hanya terdiam, dan tidak ingin menulis. Melihat kondisi siswa tersebut, bahwa dalam kegiatan menulisnya lemah dikarenakan kondisi tangannya yang kurang mampu untuk menggerakan lebih lama. Guru akan memberikan bimbingan kepada siswa tersebut. Kemudian guru meminta siswa untuk mengumpulkan tugasnya dan siswa menerima tugas dari guru untuk mempelajari kembali mengenai struktur pada teks ekplanasi. 
3) Kegiatan Penutup

Kegiatan terakhir adalah penutup, dalam tahap ini guru memberikan kesempatan kepada siswa untuk menyimpulkan hasil pembelajaran yang telah didapatkannya, salah satu siswa bernama Winda sari mengangkat tangannya, dan menyimpulkannya. Guru dan siswa memberikan apresiasi. Selanjutnya guru memberikan penguatan terhadap simpulan yang disampaikan oleh siswa. Selanjutnya guru beserta siswa mengakhiri kegiatan belajar mengajar dengan mengucap hamdalah.

\section{c. Pengamatan Siklus I}

1) Hasil observasi kegiatan pembelajaran siklus I

Saat menyampaikan materi, guru memberikan penjelasan terlalu cepat maupun memberikan gambar-gambar mengenai teks eksplanasi sehingga beberapa siswa kurang memahami dalam menerima atau menangkap materi yang diberikan. Begitupun dengan pembagian kelompok suasana di kelas menjadi ribut, sehingga guru kurang dalam mengkondisikan kelas dengan baik. Melihat kondisi kelas dengan susana ribut, guru segera menenangkan kelas dengan memberikan teguran kepada siswa yang ribut. Ketika diskusi kelompok ada beberapa siswa yang mengobrol dengan teman, mondar-mandir, dan mengantuk di kelas.

Melihat dari beberapa siswa yang tidak memperhatikan pembelajaran yang diberikan oleh guru, guru menghampiri siswa tersebut dan memberikan teguran. Guru cukup baik memberikan bimbingan kepada siswa dalam menulis teks eksplanasi dan kurang pendekatan terhadap siswa yang dalam kegiatan menulisnya lemah. Pada saat diskusi kelompok perlunya bimbingan seperti mendatangi satu persatu kelompok dan melihat siswa dalam mengerjakan tugas tersebut, untuk memberikan arahan atau ada kesulitan dalam mengerjakan tugas kelompok.

Siswa mulai mengerti mengenai gambar-gambar teks eksplanasi tersebut. Suasana kelas menjadi ramai pada saat mempersentasikan hasil diskusi dan memberikan tanggapan, guru langsung menenangkan siswa dan memberikan arahan kepada siswa yang ingin berargumen ataupun memberikan tanggapan. Setelah itu, guru meluruskan pendapat siswa menjadi lebih sesuai dengan pembahasan. Kegiatan akhir, guru memberikan kesempatan kepada siswa untuk menyampaikan simpulan terhadap pembelajaran yang telah berlangsung. Guru memberikan penguatan terhadap simpulan yang diberikan oleh siswa.

2) Hasil observasi sikap siswa siklus I

Kegiatan siswa pada proses belajar yang diamati oleh peneliti dengan memperhatikan sikap positif (on task) dan negatif (off task). Berikut ini akan dijelaskan hasil observasi sikap positif (on task) dan negatif (off task) terhadap siswa. 


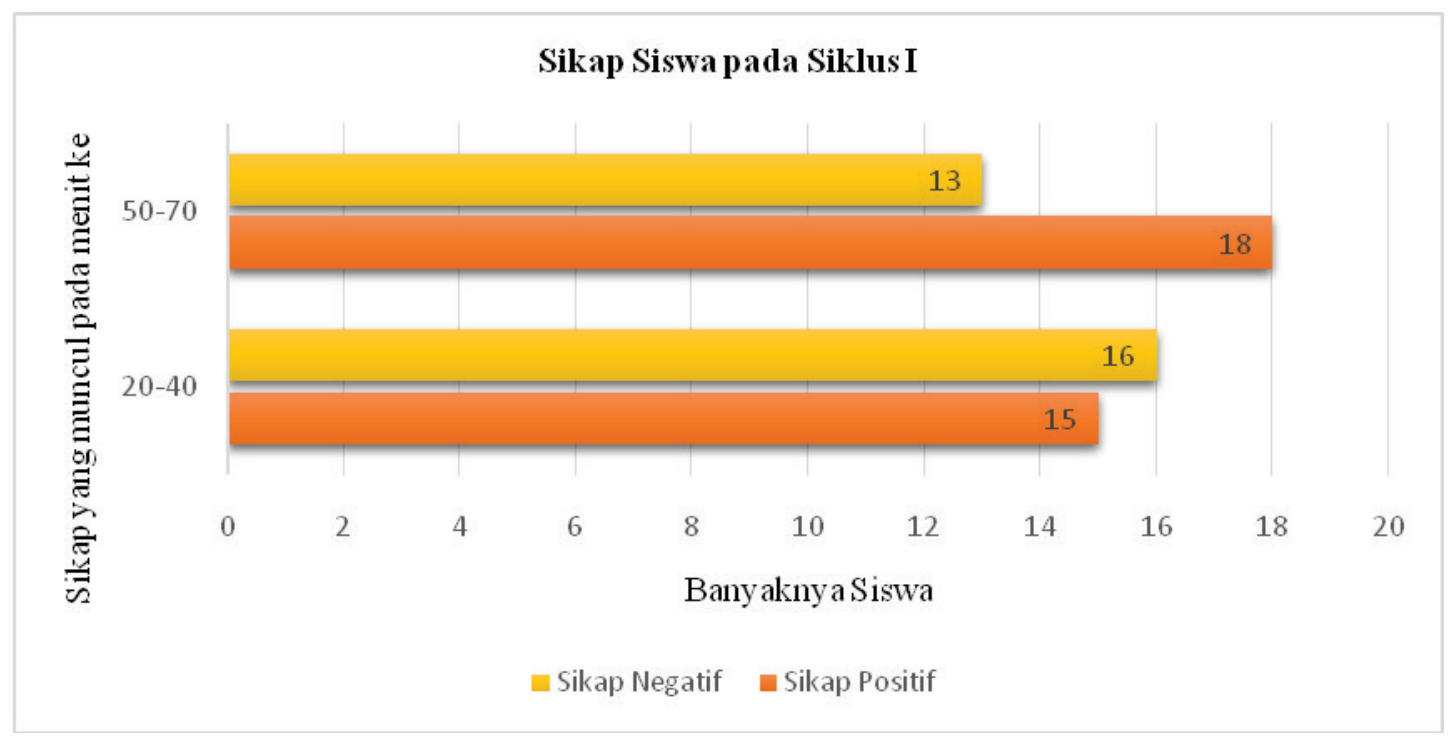

Grafik 3 Sikap Siswa Siklus I

Dari data di atas menggambarkan sikap siswa pada kegiatan pembelajaran siswa di kelas. Pada menit ke 20-40 siswa memberikan sikap negatif yang muncul ada 16 orang sedangkan siswa memberikan sikap positif yang muncul ada 15 orang. Setelah mengetahui sikap perilaku siswa yang muncul pada menit ke 20-40, mengetahui hal tersebut yang akan dilakukan oleh guru dengan menegur siswa agar tidak ribut di kelas dan siswa tidak memberikan sikap negatif kembali. Pada menit ke 50-70 siswa memberikan sikap negatif yang muncul ada 13 orang sedangkan siswa yang memberikan sikap negatif lebih banyak ada 18 orang. Sikap yang muncul pada siswa yaitu Sikap positif (on task) yang sering muncul pada siswa yaitu: memperhatikan, mencatat, mengemukakan pendapat, aktif dalam tugas kelompok, dan aktif mengerjakan tugas yang diberikan oleh guru. Sedangkan, sikap negatif (off task) yang sering muncul pada siswa yaitu: mengantuk, mengobrol, mengganggu temannya, mondar-mandir, dan mengeluh.

\section{d. Refleksi Siklus I}

Pada proses belajar terdapat beberapa yang harus diperbaiki, hal ini dapat dilihat dari aktivitas guru, siswa dan hasil menulis teks eksplanasi siswa. Oleh karena itu, perlu adanya perbaikan untuk siklus selanjutnya. hasil dari siklus satu, perbaikan yang perlu diperbaiki yaitu pembelajaran yang harus diperbaiki pada siklus II yaitu Pemberian apersepsi untuk membangkitkan semangat siswa dalam belajarnya. Penjelasan materi jangan terlalu cepat, harus lebih jelas penyampaiannya. Penugasan yang akan disampaikan oleh siswa harus jelas untuk membuat teks eksplanasi. Penguasaan kelas perlu diingatkan dengan cara memberikan teguran terhadap siswa yang ribut. Pemberian pendekatan dan bimbingan saat pembelajaran kepada siswa, dan memberikan kepedulian guru kepada siswa yang dengan keadaan kegiatan menulisnya lemah.

Berdasarkan hasil refleksi aktivitas siswa ada beberapa kekurangan dalam pembelajaran. Melihat suasana kelas, saat guru menjelaskan materi, siswa tidak 
memperhatikan pembelajaran, mengobrol, mondar-mandir, mengganggu teman, dan mengantuk di dalam kelas. Pada saat diskusi kelompok sebagian siswa ada yang bersemangat dalam mengerjakan tugas kelompok, dan siswa yang lain tidak bersemangat dan mengeluh karena tugas yang diberikan oleh guru.

Adapun pembelajaran yang harus diperbaiki pada siklus II yaitu siswa sebaiknya memperhatikan penjelasan yang disampaikan oleh guru. Siswa sebaiknya mengikuti pembelajaran dengan baik dan tidak asyik sendiri seperti mengobrol, mondar-mandir, mengganggu temannya, dan mengantuk. Siswa ikut bersemangat dan berpartisipasi pada diskusi kelompok mengenai teks eksplanasi. Siswa tidak mengeluh saat ditugaskan menulis teks eksplanasi.

1) Refleksi Hasil Menuslis Teks Eksplanasi Siswa

Melihat hasil Hasil dari menulis teks eksplanasi siswa pada siklus I, terdapat beberapa siswa yang sudah tuntas hingga mencapai nilai standar KKM 70. Akan tetapi, masih banyak siswa yang mendapat nilai di bawah standar KKM 70. Oleh karena itu, siswa di kelas VIII masih kurang dalam menulis teks eksplanasi pada saat ingin menuangkan gagasannya, dan masih ada beberapa siswa yang masih perlu memahami bagian-bagian strukturnya pada teks eksplanasi. Berikut ini adalah data hasil skor nilai menulis teks ekplanasi.

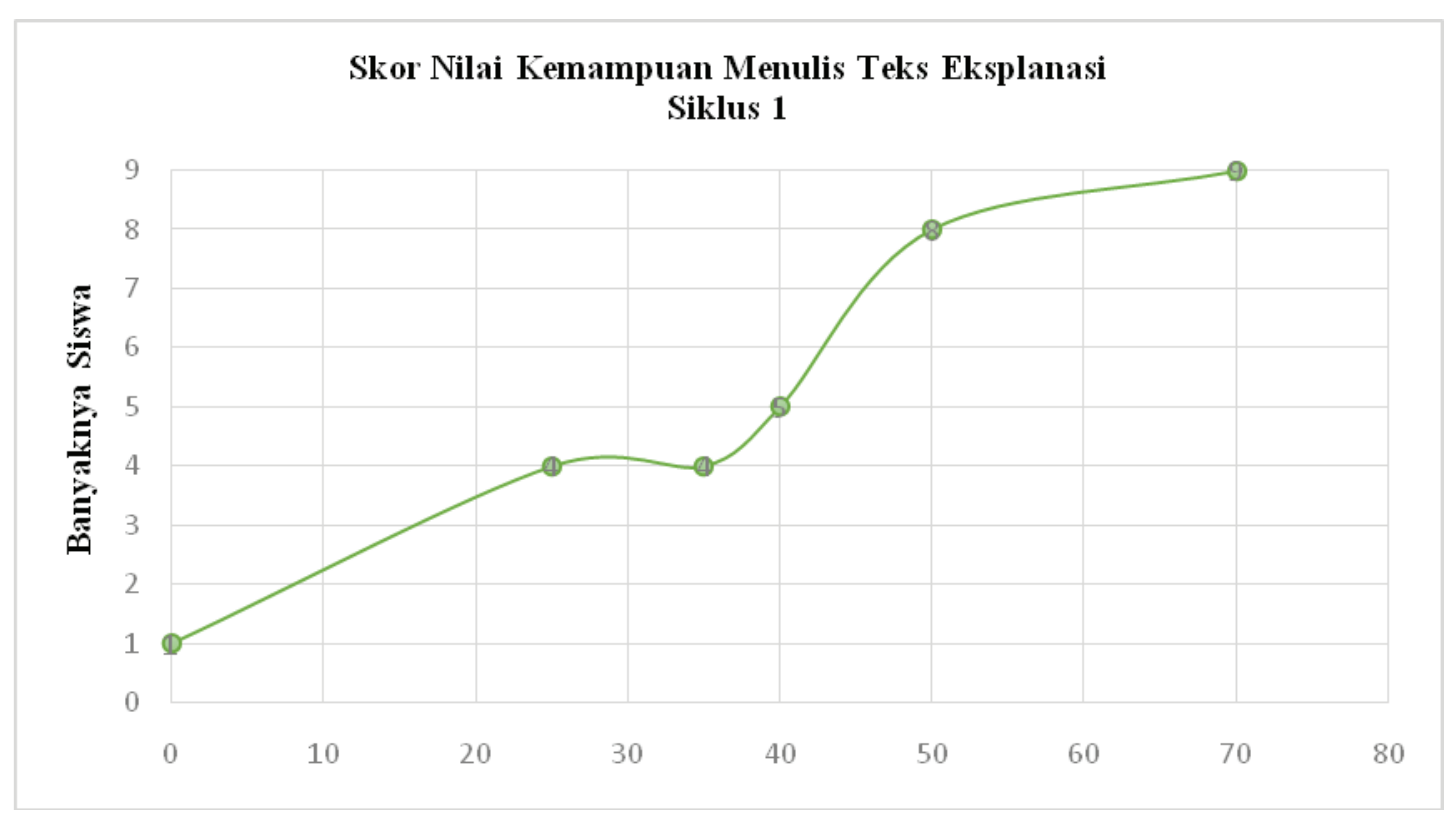

Grafik 4 Hasil Menulis Teks Eksplanasi Siklus I

Dari tabel di atas, siswa rata-rata memiliki kemampuan menulis teks eksplanasi yang kurang dari menuangkan gagasannya dan segi strukturnya, sehingga masih banyak siswa yang mendapatkan nilai di bawah 70 dengan berjumlah 22 orang, sedangkan beberapa siswa yang mendapat nilai 70 berjumlah 9 orang sehingga memenuhi standar KKM. 


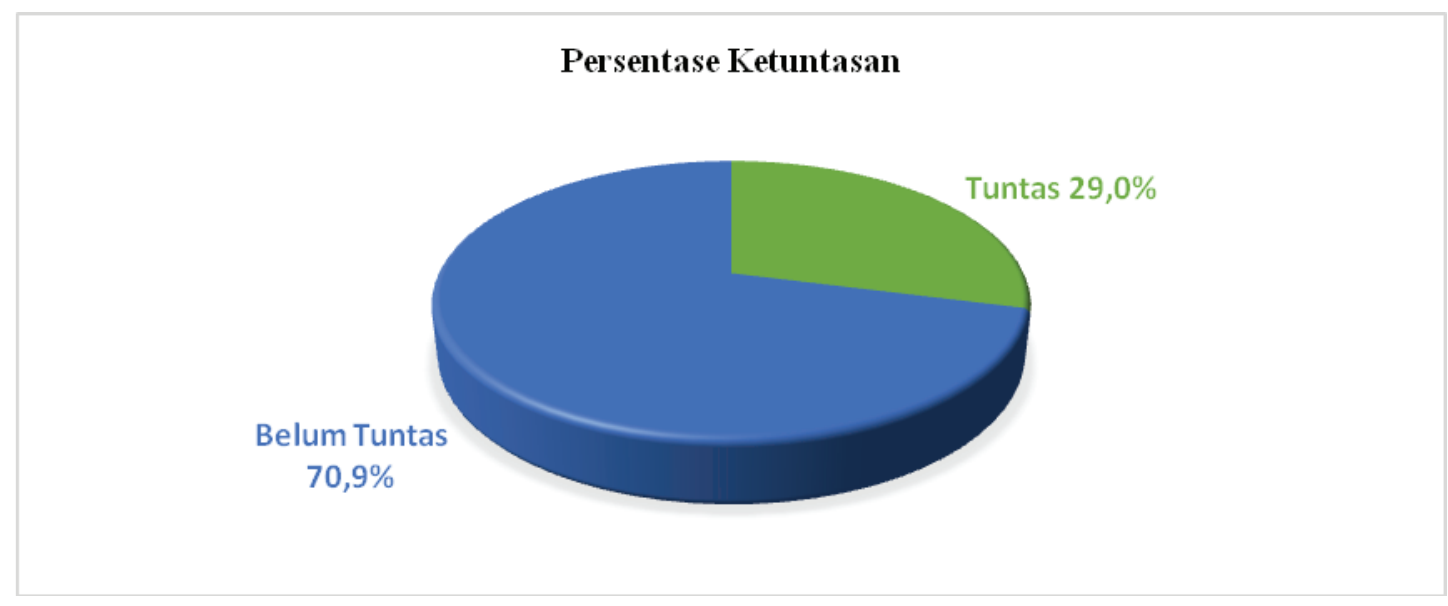

Grafik Lingkaran 5 Persentase Ketuntasan Kemampuan Menulis Teks Eksplanasi Siklus I

Berdasarkan dari grafik lingkaran tersebut, siswa yang mendapatkan nilai di bawah 70 adalah 22 siswa yang belum tuntas dengan pesentase 70,9\%. Sedangkan siswa yang mendapatkan nilai 70 yang tuntas dengan persentasi 29,0\% adalah 9 orang. Pada Siklus I ini, bahwa persentase ketuntasan siswa dalam menulis teks eksplanasi masih kurang dari $70 \%$. Hal tersebut perlunya perbaikan dengan langkah Selanjutnya yang akan dilaksanakan pada siklus II.

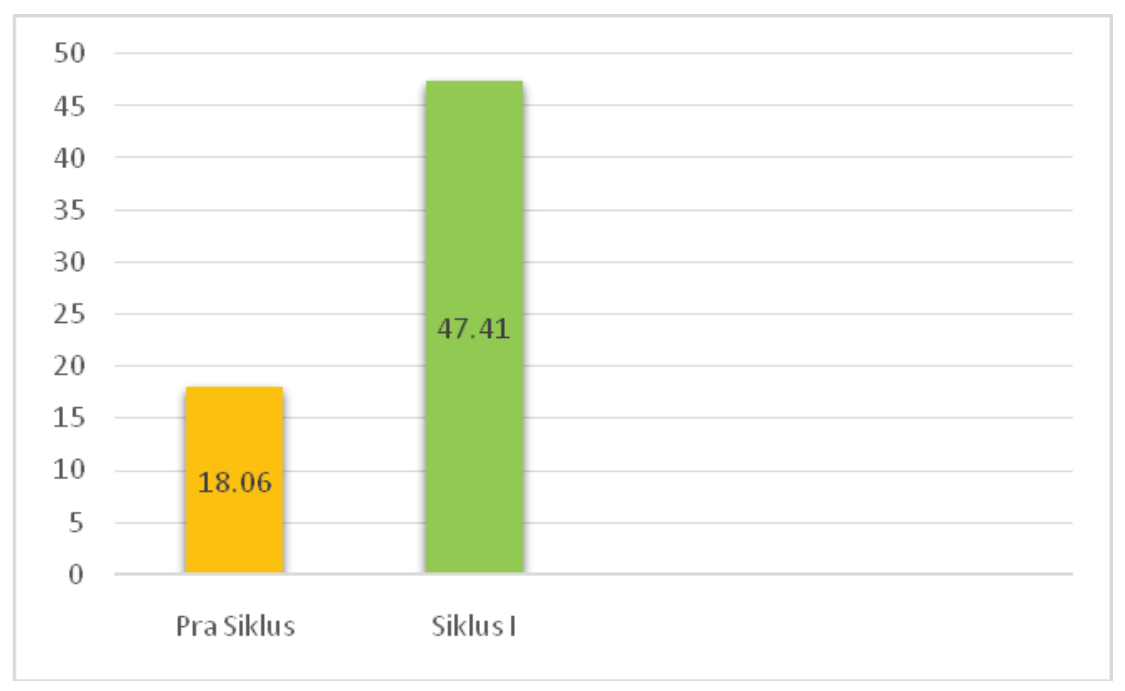

Diagram 1 Nilai Rerata Kemampuan Menulis Teks Eksplanasi Prasiklus dan Siklus I

\section{Pelaksanaan Siklus II}

a. Perencanaan

Dilihat dari siklus I, maka siklus II akan dilakukan perbaikan proses belajar. Perbaikan proses belajar yaitu memberikan apersepsi kepada siswa agar siswa bersemangat dalam mengikuti pembelajaran maupun menulis teks eksplanasi. Siswa mampu memahami teks eksplanasi melalui model example non example dengan menggunakan gambar lebih menarik agar meningkatkan aktivitas siswa dalam proses belajar. Perencanaan siklus II disusun 
berdasarkan refleksi dari siklus I. Sebelum melanjutkan ke siklus II, dilakukan perencanaan pelaksanaan siklus II (kedua). Adapun rencana yang akan dilaksanakan yaitu: (1) menyusun rencana pelaksanaan pembelajaran (RPP); (2) menyiapkan media pembelajaran; (3) menentukan waktu pelaksanaan tindakan; (4) menyiapkan lembar observasi; dan (5) membuat lembar evaluasi untuk siswa.

b. Pelaksanaan Tindakan Siklus II

Tindakan siklus II dilaksankan pada pertemuan kedua. Pertemuan yang kedua ini dilaksanakan pada hari kamis 21 Februari 2019. Pertemuan kedua ini dimulai pukul 12.4014.00 WIB. Seluruh siswa hadir sebanyak 31 orang yang terdiri atas laki-laki 16 orang dan perempuan 15 orang. Pelaksanaan pembelajaran dilakukan dengan tiga tahap, yaitu kegiatan pendahuluan, kegiatan inti, dan kegiatan penutup.

1) Kegiatan Pendahuluan

Kegiatan pendahuluan ini diawali dengan guru mengucapkan salam, mengkondisikan kelas, setelah semuanya siap guru membuka kegiatan pembelajaran dengan berdoa dan mengisi daftar hadir siswa. Selanjutnya guru menyampaikan tujuan pembelajaran yaitu: (a) siswa mampu menelaah suatu kejadian mengenai fenomena alam dalam teks eksplanasi; (b) siswa dapat menentukkan struktur dan unsur kebahasaan dalam teks eksplanasi; dan (c) siswa mampu membuat teks eksplanasi.

2) Kegiatan Inti

Pembelajaran inti diawali dengan guru memberikan apersepsi dengan membangkitkan semangat siswa agar semangat untuk mengikuti proses belajar. Guru kemudian menjelaskan materi teks eksplanasi dan bagian-bagian strukturnya dalam teks eksplanasi. Setelah itu, Guru membagikan 3 kelompok. Kemudian tiap-tiap kelompok untuk memperhatikan gurunya terlebih dahulu. Guru memberikan kertas yang sudah digulung menjadi tiga kertas gulung kata kunci, dan tiga kartu gulung penjelasan. Sebelum siswa memilih kertas tersebut, guru membagikan tiga kelompok terlebih dahulu, telah dibagi menjadi tiga kelompok, tiap-tiap kelompok maju ke depan kelas untuk mengambil satu kartu gulung kata kunci dan satu kartu gulung penjelasan untuk perwakilan tiap-tiap siswa. Tiap-tiap kelompok mengambil kertas tersebut. Guru menempelkan sebuah gambar yang sudah disusun sesuai petunjuk agar siswa memahami dan menangkap yang akan disampaikan oleh guru. Guru membuat kolom tiap-tiap kelompok.

Guru memberikan arahan kepada siswa untuk membuka kartu tersebut, dan ditempelkan di papan tulis sesuai kolom yang sudah disediakan. Guru memberikan penjelasan mengenai kartu yang sudah ditempelkan di Papan tulis tersebut. Melihat siswa yang sangat aktif untuk mengungkapkan argumenya mengenai kartu tersebut. Bahwa kartu tersebut menjelaskan bagian-bagian struktur yang ada pada teks eksplanasi. Guru meminta dua perwakilan kepada siswa untuk menyatukan kartu tersebut dan menempelkan pada gambar yang sudah disiapkan. Guru memberikan 
penjelasan dan menugaskan siswa untuk membuat teks eksplanasi sesuai bagianbagiannya yang sudah ditentukan.

Guru memberikan petunjuk kepada siswa untuk mencatat hasil diskusi. Tiap-tiap kelompok diberi kesempatan membacakan hasil diskusinya, dan kelompok yang lain memberikan tanggapan. Setelah itu selesai diskusi kelompok, guru menyimpulkan hasil pembelajaran yang telah berlangsung, dan guru memberikan evaluasi kepada siswa untuk membuat teks eksplanasi. Guru memberikan pendekatan dan bimbingan kepada Syafiq untuk menulis teks eksplanasi tersebut. Kemudian guru meminta siswa untuk mengumpulkan tugasnya dan siswa menerima tugas dari guru untuk mempelajari kembali mengenai struktur pada teks ekplanasi.

3) Kegiatan Penutup

Kegiatan terakhir adalah penutup, dalam tahap ini guru memberikan kesempatan kepada siswa untuk menyimpulkan hasil pembelajaran yang telah didapatkan. Selanjutnya guru memberikan penguatan terhadap simpulan yang disampaikan oleh siswa. Selanjutnya guru beserta siswa mengakhiri kegiatan belajar mengajar dengan mengucap hamdalah.

c. Pengamatan Siklus II

Berdasarkan hasil observasi bahwa proses belajar siswa sudah lebih baik dari pelaksanaan kegiatan menulis teks eksplanasi pada siklus I. Siswa lebih aktif dan bersemangat dalam belajar pada menulis teks eksplanasi. Kegiatan siswa selama mengikuti proses belajar diamati oleh peneliti dengan memperhatikan sikap positif dan negatif (on task dan off task). Berikut penjelasan hasil observasi sikap positif dan negatif yang diamati oleh peneliti, sebagai berikut.

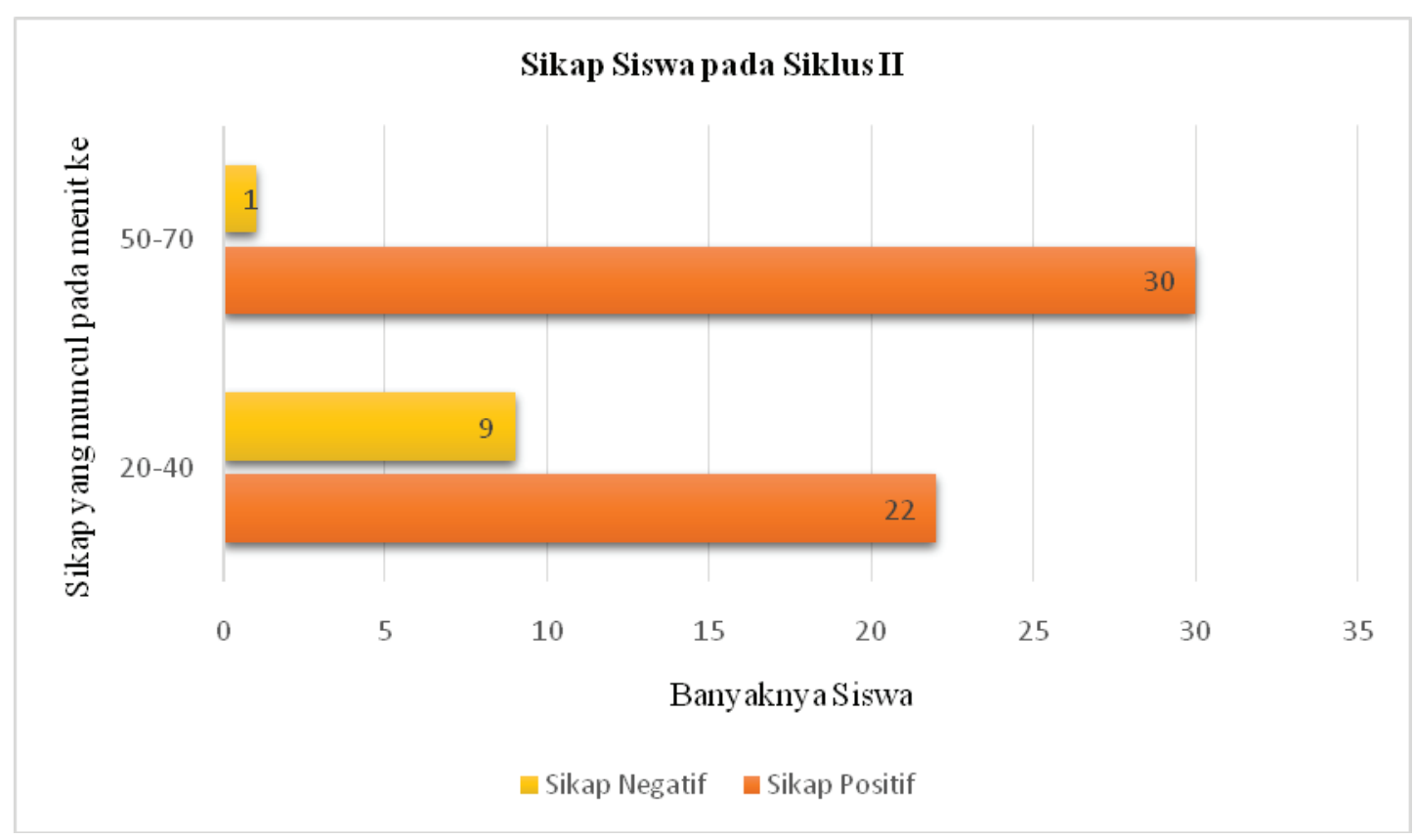

Grafik 6 Sikap Siswa Siklus II 
Pada grafik di atas, dapat dilihat pada menit ke 20-40 siswa memberikan sikap negatif lebih sedikit yaitu ada 9 orang, sedangkan siswa yang memberikan sikap positif yaitu ada 22 orang. Selanjutnya pada menit ke 40-70 siswa memberikan sikap negatif hanya satu orang dan siswa yang memberikan sikap positif hampir seluruhnya yaitu ada 30 orang. Sikap yang muncul pada siswa yaitu siswa lebih aktif dalam tugas kelompok, aktif dalam mengerjakan tugas yang diberikan guru, memperhatikan, mengungkapkan pendapat, dan memberikan tanggapan. Adapun siswa yang mencatat dan merangkum apa yang disampaikan oleh guru, maupun tugas kelompok, dan sebagian kecil siswa beberapa ada yang mengobrol.

d. Refleksi Siklus II

Berdasarkan hasil observasi aktivitas guru pada siklus sebelumnya pada siklus I masih cukup dan pada siklus II lebih baik, sebagai berikut:

1) Guru menyampaikan apersepsi kepada siswa.

2) Guru memotivasi siswa agar siswa bersemangat mengikuti kegiatan pembelajaran menulis teks eksplanasi.

3) Guru memberikan penjelasan pada materi menulis teks eksplanasi dengan menggunakan model example non example.

4) Guru memberikan petunjuk dan membimbing siswa pada diskusi kelompok.

5) Guru memberikan pendekatan kepasa salah satu siswa yang memiliki disabilitas.

6) Guru telah menguasai kelas, dan siswa sangat aktif.

7) Guru memberikan kesempatan kepada siswa untuk menyampaikan kesan pada kegiatan pembelajaran yang telah berlangsung.

Adapun hasil menulis teks eksplanasi pada siswa kelas VIII sebagai berikut.

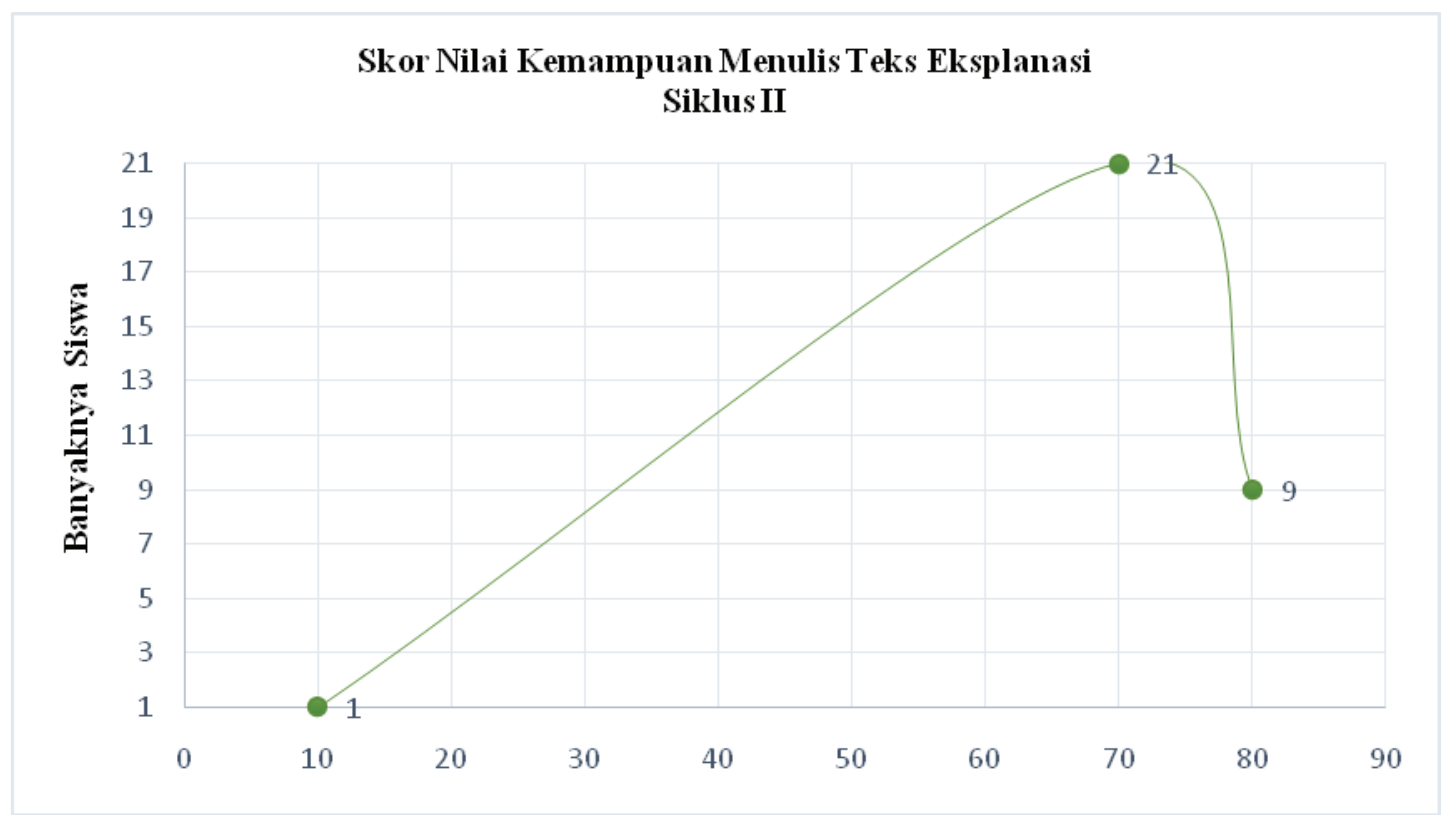

Grafik 7 Hasil Menulis Teks Eksplanasi Siklus II 
Pada grafik di atas, siswa rata-rata memiliki kemampuan menulis teks eksplanasi dan dapat menuangkan gagasannya dari segi isi dan segi strukturnya, yaitu terdapat beberapa siswa yang mendapatkan nilai di atas 70. sedangkan siswa yang mendapat nilai hingga memenuhi standar KKM. Sedangkan salah satu siswa sudah berusaha dan masih perlu pendekatan dan bimbingan lebih pada siswa yang memiliki kegiatan menulisnya lemah, dikarenakan tangan yang kurang mampu bergerak lama atau menulis .

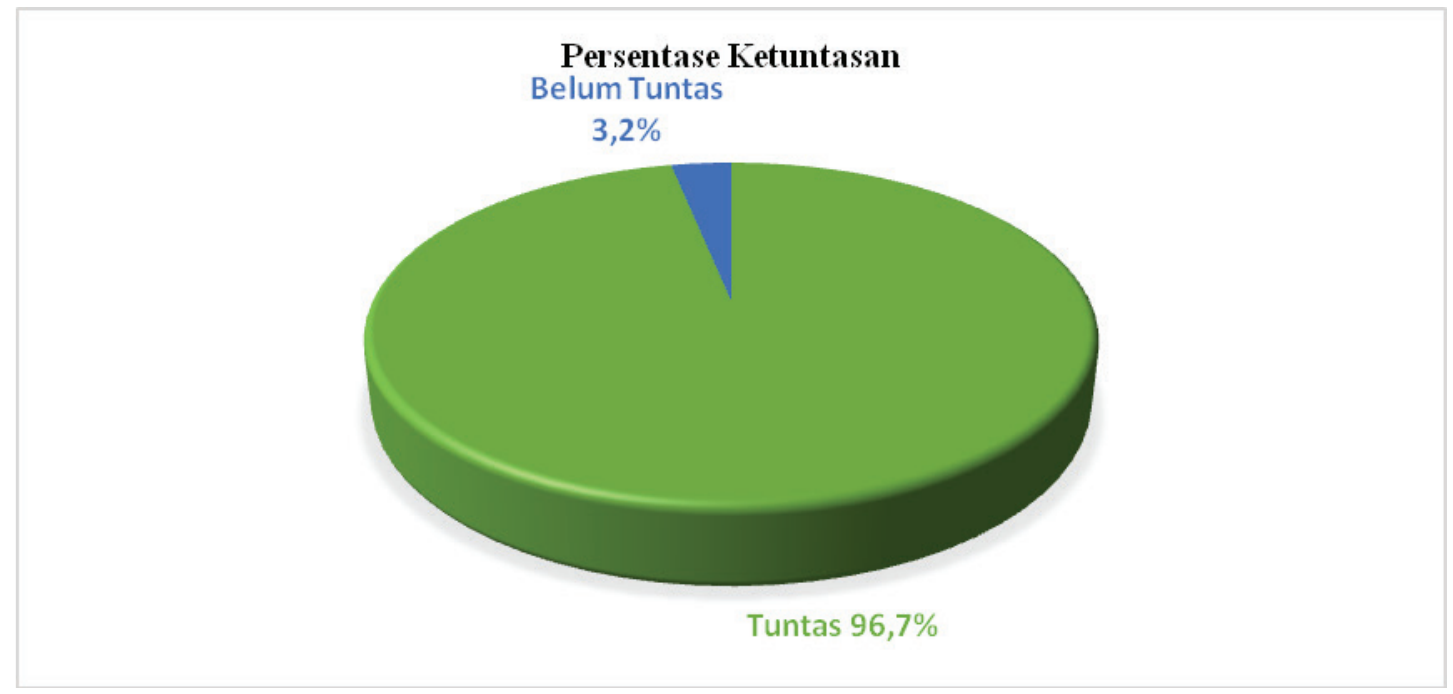

Tabel 12 Persentase Ketuntasan Kemampuan Menulis Teks Eksplanasi Siklus II

Berdasarkan dari grafik lingkaran tersebut, siswa yang mendapatkan nilai di bawah 70 adalah hanya satu siswa yang belum tuntas dengan pesentase 3,2\%. Sedangkan siswa yang mendapatkan nilai 70 ke atas yang tuntas dengan persentasi 96,7\%. Siklus II ini bahwa persentase ketuntasan siswa dalam menulis teks eksplanasi meningkat lebih dari $70 \%$. Hal tersebut hasil menulis siswa meningkat dengan menggunakan model example non example dengan menggunakan media gambar.

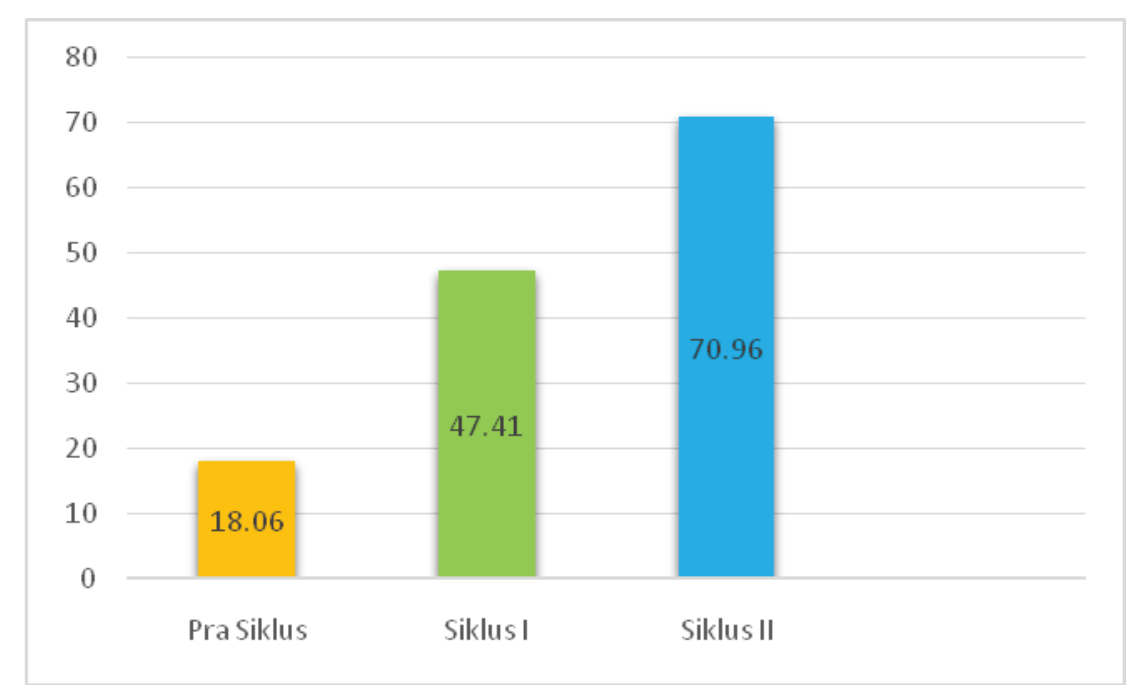

Diagram2 Nilai Rerata Kemampuan Menulis Teks Eksplanasi Prasiklus, Siklus I, dan Siklus II 
Penerapan model example non example dilakukan pada prasiklus, siklus I dan siklus II ini dapat dilihat bahwa model pembelajaran dengan menggunakan media gambar dapat menarik perhatian siswa dalam mengikuti pembelajaran. Siswa dapat menggeneralisasikan gambar-gambar antara example dan non example yang menjelaskan gambar-gambar tersebut. Siswa dapat memikirkan perbedaan apa yang terdapat pada dua gambar tersebut, dan dapat memahami dan menuangkan gagasan-gagasan yang dapat siswa pikirkan untuk mendorong siswa memahami yang telah dilihat dan dibuat sehingga mampu memahami konsep yang baru. Hasil kemampuan menulis teks eksplanasi yang didapatkan oleh siswa selalu meningkat dari nilai rerata prasiklus $18,06 \%$, Siklus I 47,41\%, dan Siklus II 70,96\% bahwa dengan menggunakan model example non example ini dapat membuat siswa lebih semangat dalam hal menulis dan tidak membosankan, dan efektif.

\section{PENUTUP}

Berdasarkan hasil penelitian dan pembahasan yang telah dilakukan dapat diketahui bahwa penerapan model example non example dengan menggunakan media gambar dapat memberikan semangat belajar dan mampu memahami pada pembelajaran teks eksplanasi sehingga siswa dapat menuangkan ide gagasannya dengan menulis teks ekplanasi yang diberikan oleh gurunya. Siswa juga dapat memacu semangat belajar dalam mengikuti pembelajaran. Sikap siswa dapat lebih aktif, siswa mampu untuk mengungkapkan ide gagasannya, dan meningkatnya kemampuan menulis teks eksplanasi. Dengan penerapan model example non example menggunakan media gambar dapat meningkatkan kemampuan menulis siswa dari mulai prasiklus, siklus I, dan siklus II dapat mencapai 70,96\% dan tingkat ketuntasannya mencapai 96,7\%.

\section{DAFTAR PUSTAKA}

Agustin, Mubiar. (2011). Permasalahan Belajar dan Inovasi Pembelajaran. Bandung: PT Refika Aditama.

Akbar, Sa'dun. (2016). Instrumen Perangkat Pembelajaran. Bandung: PT Remaja Rosdakarya.

Arikunto, S. (2014). Prosedur Penelitian: Suatu Pendekatan Praktik. jakarta: Rineka Cipta.

Chotimah, C. dan Fathurrohman, M. (2018). Paradigma Baru Sistem Pembelajaran. Yogyakarta: Ar-Ruzz Media.

Dalman, H. (2014). Keterampilan Menulis. Jakarta: Rajawali.

Hamdayama, Jumanta. (2014). Model dan Metode Pembelajaran Kreatif dan Berkarakter. Bogor: Ghalia Indonesia.

Hanafiah, N. dan Suhana, C. (2012). Konsep Stategi Pembelajaran. Bandung: PT Refika Aditama. 
Iskandarwassid dan Sunendar, D. (2013). Strategi Pembelajaran Bahasa. Bandung: PT Remaja Rosdakarya.

Kadir, Abdul. (2012). Dasar-Dasar Pendidikan. Jakarta: Prenada Media Group.

Khuzaemah, E dan Herawati. L. (2017). Pembelajaran Menulis Esai Menggunakan Model Cooperative Integrated Reading And Composition (Circ) Berbasis Life Skills. Journal Indonesian Language Education and Literature, 2(2), 148-162.

Kosasih. (2017). Bahasa Indonesia. Jakarta: Kementerian Pendidikan dan Kebudayaan.

Kunandar. (2012). Langkah Muda Penelitian Tindakan Kelas sebagai Pengembangan Profesi Guru. Jakarta: Rajawali Press.

Kurniawan, Asep. (2018). Teori dan Praktek Penelitian Tindakan Kelas. Cirebon: Eduvision.

Mahsun. (2018). Pembelajaran Bahasa Indonesia Berbasis Teks. Depok: PT Raja Grafindo Persada.

Muttaqin, M. Z. (2017). Pengembangan Instrumen Penilaian Tes Tertulis Bentuk Uraian Untuk Pembelajaran PAI Berbasis Masalah Materi Fiqh. JURNAL TATSQIF, 15(2503-4510), $1-23$.

Nasir, M. (2017). Metode Penelitian. Bogor: Ghalia Indonesia.

Sa'adah, A., Sugiyanto., dan Sutarman. (2013). Pengembangan instrumen tes benar-salah untuk menilai kemampuan berpikir tingkat tinggi siswa pada materi dinamika rotasi dan kesetimbangan benda tegar. Jurnal Online Universitas Negeri Malang.

Sanjaya, Wina. (2011). Perencanaan dan Desain Sistem Pembelajaran. Jakarta: Prenada Media Group.

. (2014). Strategi Pembelajaran Berorientasi Standar Proses Pendidikan. Jakarta: Prenada Media Group.

Siregar, E. dan Nara, H. (2015). Teori Belajar dan Pmbelajaran. Bogor: Ghalia Indonesia.

Sumadayo, S. (2013). Penelitian Tindakan Kelas. Yogyakarta: Graha Ilmu

Sukino. (2012). Menulis Itu Mudah. Yogyakarta: PT LkiS Printing Cemerlang.

Sukardi. (2015). Metodologi Penelitian Pendidikan. Jakarta: PT Bumi Aksara. 
Syamsudin, A. (2014). Pengembangan Instrumen Evaluasi Non Tes (Informal) untuk Menjaring Data Kualitatif Perkembangan Anak Usia Dini. Jurnal Pendidikan Anak, 5(2882 - 8276), 403-413.

Perdata, I. B. K. (2013). Instrumen Observasi Kegiatan Inti Pembelajaran Matematika Berbasis Pendekatan Saintifik (5m) Di Sma. Jurnal SANTIAJI PENDIDIKAN, 6(2087 - 9016), 126-147.

Purnomo, Bambang Hari. (2011). "Metode dan Teknik Pengumpulan Data dalam Penelitian Tindakan Kelas”. Jurnal Pengembangan Pendidikan, 251-256.

Putra, Nusa. (2013). Metode Penelitian Kualitatif Pendidikan. Jakarta: PT RajaGrafindo Persada.

Rusmini. 2018. KemampuanMenulisTeksProsedurSiswaKelas VIII SMP Negeri 1 Segeri Kabupaten Pangkep. Skripsi. Makassar: Uniersitas Negeri Makassar.

Tarigan, Henry Guntur. (2008). Menulis Sebagai Suatu Keterampilan Berbahasa. Bandung: Angkasa.

Warsono dan Hariyanto. (2013). Pembelajaran Aktif. Bandung: PT Remaja Rosdak. 